\title{
DISTRIBUTION OF PCBs IN SEDIMENTS OF THE ČERVENÝ POTOK, STREAM CONTAMINATED BY TECHNICAL PCB MIXTURES DELOR, CZECH REPUBLIC
}

\author{
PETRA HNAŤUKOVÁ ${ }^{1)}$, HELENA BUREŠOVÁ ${ }^{2,3)}$, LUCIE KOCHÁNKOVÁ ${ }^{3)}$ \\ JITKA BÄUMELTOVÁ1) \\ ${ }^{1)}$ Institute of Hydrodynamics AS CR, v.v.i., Pod Patankou 5, 16612 Prague 6, Czech Republic; Mailto: hnatukova@ih.cas.cz \\ ${ }^{2)}$ Institute of Environmental Studies, Faculty of Science, Charles University in Prague, Benatska 2, 12801 Prague 2, Czech \\ Republic; Mailto: helen.bures@seznam.cz \\ ${ }^{3)}$ Department of Environmental Chemistry, Faculty of Environmental Technology, Institute of Chemical Technology Prague, \\ Technicka 5, 16628 Prague 6, Czech Republic; Mailto: lucie.kochankova@vscht.cz
}

The results of measurement of polychlorinated biphenyls (PCBs) in surface bottom sediments contaminated by technical PCB mixtures Delor collected from the Červený potok (stream in the Litavka River catchment), Czech Republic in 2008 are presented. The sediment samples of two different grain size fractions $(<2 \mathrm{~mm}$ and $<200 \mu \mathrm{m})$ were analyzed for 8 congeners of PCBs using Soxhlet extraction and gas chromatography (GC-ECD). Total concentrations of PCBs ranged from 15.3 to $997 \mathrm{ng} \mathrm{g}^{-1}$ (dry weight) in $<2 \mathrm{~mm}$ fraction and from 29.9 to $952 \mathrm{ng} \mathrm{g}^{-1}$ in $<200 \mu \mathrm{m}$ fraction, where PCBs $28,52,101,138,153$, 180 and 194 were found in all the samples. The highest levels of PCBs were found in sediment collected from the area below the discharge of municipal wastewater treatment plant and local engineering industry in the Komárov village. High percentage of PCBs 28, 153 and 138 (22-74\%, 5-22\% and 5-20\% respectively) indicates the contamination by PCBs commercial mixtures Delor 103 and Delor 105 (an equivalent of AROCLOR 1242 and 1254). The result of PCA analysis indicates that the more highly chlorinated PCB congeners tend to be more associated with finer organic carbon particles of the $<200 \mu \mathrm{m}$ sediment fraction.

KEY WORDS: PCBs (Polychlorinated Biphenyls), Sediments, Delor, TOC (Total Organic Carbon), PCA (Principal Component Analysis).

Petra Hnatuková, Helena Burešová, Lucie Kochánková, Jitka Bäumeltová: DISTRIBUCE PCB V SEDIMENTECH ČERVENÉHO POTOKA KONTAMINOVANÉHO TECHNICKÝMI SMĚSMI DELOR, ČESKÁ REPUBLIKA. J. Hydrol. Hydromech., 58, 2010, 1; 20 lit., 4 obr., 1 tab.

Práce se zabývá distribucí polychlorovaných bifenylů (PCB) v povrchových sedimentech Červeného potoka (povodí Litavky), kontaminovaných technickými směsmi Delor. Ve dvou zrnitostních frakcích sedimentů $(<2 \mathrm{~mm}$ a $<200 \mu \mathrm{m})$ odebraných v roce 2008 byly prostřednictvím Soxhletovy extrakce a plynové chromatografie (GC-ECD) stanoveny koncentrace 8 indikačních kongenerů PCB. Celkové koncentrace PCB se v zrnitostní frakci $<2 \mathrm{~mm}$ pohybovaly od 15,3 do $997 \mathrm{ng} \mathrm{g}^{-1}$ sušiny, ve frakci $<200$ $\mu \mathrm{m}$ bylo rozpětí koncentrací 29,9 až $952 \mathrm{ng} \mathrm{g}^{-1}$ sušiny. PCB kongenery 28, 52, 101, 138, 153, 180 a 194 byly naměřeny ve všech vzorcích sedimentů. Z výsledků vyplývá, že nejvyšší koncentrace PCB byly zjištěny $\mathrm{v}$ sedimentech odebraných $\mathrm{z}$ lokality pod zaústěním odtoku z čistírny odpadních vod v obci Komárov, do které ústí i kanalizační větev z místního strojírenského podniku. Vysoké procentuální zastoupení kongenerů PCB 28, 153 a 138 (22-74\%, 5-22\% a 5-20\%) v sumě všech osmi kongenerů značí kontaminaci technickými směsmi Delor 103 a Delor 105 (srovnatelných se směsmi AROCLOR 1242 a 1254). Z výsledků PCA analýzy vyplývá, že vícechlorované kongenery PCB jsou intenzivněji asociovány s organickou hmotou v jemnější frakci sedimentu $<200 \mu \mathrm{m}$.

KLÍČOVÁ SLOVA: polychlorované bifenyly (PCB), sedimenty, Delor, celkový organický uhlík (TOC), analýza hlavních component (PCA).

\section{Introduction}

Polychlorinated biphenyls (PCBs) are toxic and highly persistent organic compounds. PCBs consist of 209 congeners differing in the number and position of chlorine atoms on the two coupled biphenyl rings, but only about 130 of these are likely to occur in commercial products or mixtures (Safe, 
1990). In the last decades, several hundred tons of PCBs have been released into the environment. Their chemical stability, lipid solubility and ubiquitous occurrence in the environment made them one of the most widespread contaminants in the environment (Krauss, 2000). Due to their hydrophobic properties, PCBs tend to be adsorbed by natural organic matter in soil, sediment, and sludge. In addition to being persistent and toxic, the PCBs are bioaccumulative and have been shown to exhibit endocrine disruption in fish and wildlife (Nakata et al., 2003; Dercová et al., 2009).

Once they are released into the aquatic environment, hydrophobic PCBs may become adsorbed on particles of suspended matter in the water column or deposited on the surface of sediment (Hulscher et al., 2002). Although most pollutants adsorbed on sediments are not readily available to aquatic organisms, variation of $\mathrm{pH}$, salinity, redox potential, content of organic chelators and hydrodynamic parameters may induce their release back to the aqueous phase (Hnatuková et al., 2009; Volaufova, Langhammer, 2007). Many physicochemical processes significantly influence the occurrence of PCBs in water, such as sedimentation, diffusion, degradation and evaporation. These processes affect to a large degree the transport of PCBs among environmental compartments via evaporation into the air, dissolution in the water column, adsorption onto suspended particles, bioaccumulation in the organisms and sorption onto an immobile deep sediment layer storing the pollutant in inactive form (Gdaniec-Pietryka et al., 2007). Sorption onto mobile superficial fraction of sediment is extremely important, as it can both immobilize and remobilize pollutants and increase or decrease their degradation.

Most of the PCBs were produced during the period 1950 to 1983 worldwide (Tanabe, 1988). In the former Czechoslovakia, PCBs were manufactured from 1959 to 1984 in a chemical plant in eastern Slovakia under the commercial name Delor. From the total $21482 \mathrm{t}$ produced, $46 \%$ was exported and the remainder was appointed for the home market of former Czechoslovakia (Holoubek, 2000; Breivik et al., 2002). In the Czech Republic, PCB formulations may be currently used only in the closed systems and they are gradually replaced. Currently, waste landfillings are considered to be the most relevant source of environmental pollution by PCBs, although significant contribution of industrial and municipal waste incinerators and dis- charges of municipal wastewater treatment plants were reported (Samara, 2006).

The objectives of this work were to provide characterization of PCB-contaminated superficial sediments sampled from the Červený potok, stream which is substantially contaminated by the PCB commercial mixtures Delor and to identify the possible source of the contamination. The concentrations of PCBs were measured in two different grain sizes fractions of freeze dried sediment in order to evaluate the relationship between total organic carbon (TOC) content and PCBs concentrations. The multivariate data analysis technique of principal component analysis (PCA) was used in the classification of $\mathrm{PCB}$ congeners distribution, TOC content and the quantitative identification of the possible source of the contamination.

\section{Materials and methods}

\subsection{Study area}

The Červený potok is a left-hand tributary of the Litavka River in the west part of the Czech Republic (Fig. 1). Its lengths is $26.8 \mathrm{~km}$ with the catchment of $138 \mathrm{~km}^{2}$, the annual mean discharge at the confluence with the Litavka River in Zdice is 0.65 $\mathrm{m}^{3} \mathrm{~s}^{-1}$. The stream springs in the forest of the military zone Brdy and flows north-east through agricultural area with several villages and through two towns Hořovice and Zdice.

\subsection{Chemicals}

The following reagents were used: acetone (Analytika, Czech Republic), n-hexane (Analytika, Czech Republic), isooctane (Analytika, Czech Republic), methanol (Analytika, Czech Republic), standard PCB MIX-1 (Analytika, Czech Republic), certified reference material of stream sediment Metranal $^{\mathrm{TM}} 14$ (Analytika, Czech Republic), and florisil (Supelco, USA).

\subsection{Sediment sampling and processing}

The mixed samples of fine grained stream sediments were sampled up to the depth of $5 \mathrm{~cm}$ at six sampling sites of the Červený potok in spring 2008, using a plastic trowel near the bank of the stream. About $1 \mathrm{~kg}$ of surface sediment was collected into clean polyethylene containers and frozen immediately on returning to the laboratory. The samples were then freeze dried (CHRIST ALPHA 1-4) and 


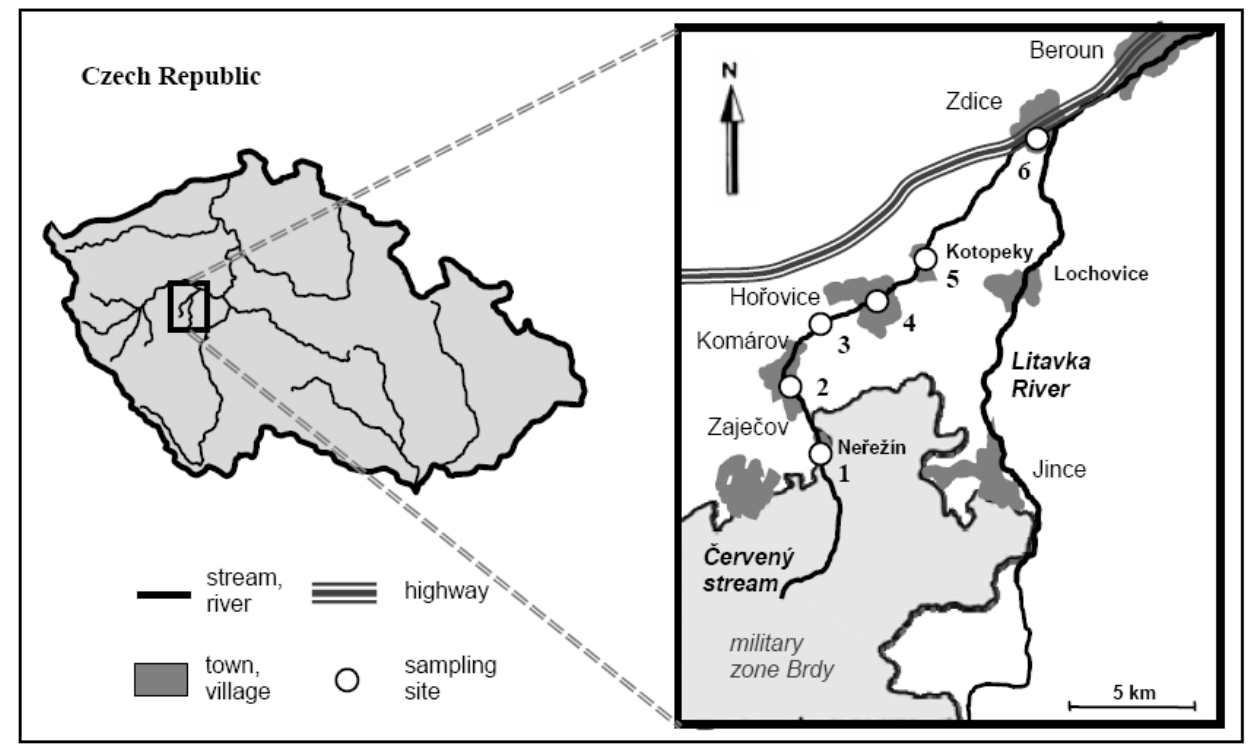

Fig. 1. Location of the study area and stream sediment sampling sites. Obr. 1. Lokalizace zájmového území a odběrových míst sedimentů.

sieved through $2 \mathrm{~mm}$ and $200 \mu \mathrm{m}$ mesh nylon sieves in order to obtain sediment samples of the different grain size $(<2 \mathrm{~mm}$ and $<200 \mu \mathrm{m})$.

Isolation of target analytes from sediment samples was carried out by Soxhlet extraction in three replicates. $10 \mathrm{~g}$ of sediment sample was extracted $16 \mathrm{~h}$ in $200 \mathrm{ml}$ Soxhlet apparatus using $300 \mathrm{ml}$ of the solvent mixture, hexane : acetone $(2: 1, \mathrm{v} / \mathrm{v})$. All extracts were concentrated using rotary evaporator (Laborota 4002 control, Heidolph, Germany) and purified through SPE cartridge of florisil $(6 \mathrm{ml}$, $1 \mathrm{~g}$, Supelco, USA). The relative standard deviations (RSDs) for Soxhlet replicates were lower than $30 \%$ for all PCB congeners.

\subsection{PCB and TOC analysis}

PCB indicator congeners (IUPAC no. 28, 52, $101,118,138,153,180$ and 194) were analyzed with an Agilent Technologies 6890N GC system (USA) using a ${ }^{63} \mathrm{Ni}$ electron capture detector (ECD). Separation was accomplished on a capillary non-polar column HP-5 (30 m x $0.32 \mathrm{~mm}$ inner diameter) coated with $0.25 \mu \mathrm{m}$ (5\%-phenyl)methylpolysiloxane phase, with helium as a carrier gas and splitless injection of one microlitre of the extract. The temperature program was $80{ }^{\circ} \mathrm{C}$ for 2 min, followed by an increase at a rate of $20{ }^{\circ} \mathrm{C}$ $\min ^{-1}$ until the temperature reached $200{ }^{\circ} \mathrm{C}$, and then followed by an increase at a rate of $10^{\circ} \mathrm{C} \mathrm{min}^{-1}$ until the temperature reached $280{ }^{\circ} \mathrm{C}$. Quantitative evaluation of the results was performed based on comparison of the peak areas corresponding to the indicator congeners in the chromatograms of the sample and of the standard (Astasol ${ }^{\circledR}$ PCB MIX-1). Procedural blanks were run and taken through all phases of the analytical procedure. The RSDs for triplicate measurements of 20 randomly selected replicates were lower than $10 \%$ for all analyzed PCB congeners. The accuracy of the extraction and analytical procedures were checked using sediment reference material Metranal ${ }^{\mathrm{TM}}$ 14. Analysis of this reference material showed satisfactory accuracy, with recovery rates from $83 \%$ to $117 \%$ for all analyzed PCB congeners except PCB 118.

TOC analysis of freeze dried sediment was performed in three replicates using Shimadzu TOC$5000 \mathrm{~A}$ (Japan) converting the organic carbon to $\mathrm{CO}_{2}$, equipped with a non-dispersive infrared gas analyzer. The RSDs for TOC analysis replicates were lower than $2 \%$.

\subsection{Data analysis}

Principal component analysis (PCA) was used to study the correlation structure of PCBs and TOC and for the indication of associations between samples and variables. PCBs concentrations and TOC contents underwent linear PCA (a particular type of factor analysis) using the Canoco program (Ter Braak, Smilauer, 2002). Principal components are calculated by linear combinations of the original 
variables taken as orthogonal to one another. The first principal component accounts for the maximum amount of variance and subsequent principal component explain successively smaller quantities of the original variance. The computed principal component score plot shows the samples as points and the variables as vectors. Each sample can be conceived as a point in a $k$-dimensional space, where $k$ is a number of variables taken into account. The vector lengths indicate the variability associated with a single variable, and the cosine of the angle between the vectors reflects the degree of correlation between variables.

\section{Results and discussion}

Tab. 1 gives the concentration levels of the individual PCB congeners in sediment samples of both grain size fractions in a $\mathrm{ng} \mathrm{g}^{-1}$ on dry weight basis, $\Sigma 8$ PCBs and TOC contents. All PCB congeners were observed in most of the investigated sediment samples, but PCB congener 118 was not detected in $<2 \mathrm{~mm}$ fraction in the sampling site 2 and in $<200$ $\mu \mathrm{m}$ fraction in the sampling sites 1 and 2 . In the sampling site 3 located in the Komárov village, the highest $\Sigma 8$ PCB concentrations 997 and $952 \mathrm{ng} \mathrm{g}^{-1}$ were found in both sediment grain size fraction $<2$ $\mathrm{mm}$ and $<200 \mu \mathrm{m}$, respectively.
Composition of individual PCB congeners found in both sediment grain size fractions is percentually visualised in Fig. 2. PCB 28 predominated in PCB composition in both sediment fractions in all sampling sites except the first one. The most abundant PCB congener 28 constituted $42-73 \%$ of the total amount of PCBs in the five sites, however, in the first sampling site PCB 28 represented only about $21 \%$ of the total amount of PCBs. PCB 101 and PCB 153 predominated in the first sampling site located in Neřežín village, $2 \mathrm{~km}$ from the spring of the Červený potok. PCB 101 represented up to $29.9 \%$ and $\mathrm{PCB} 153$ up to $24.5 \%$ of the total amount of PCBs in the first sampling site.

High concentrations of PCB 28 accounting for 737 and $575 \mathrm{ng} \mathrm{g}^{-1}$ were found in sediment fractions $<2 \mathrm{~mm}$ and $<200 \mu \mathrm{m}$ in the third sampling site, respectively. Concentrations of PCB 28 then decreased in following sampling sites along the longitudinal profile of the stream, but were still high $\left(146-262 \mathrm{ng} \mathrm{g}^{-1}\right)$. In the third sampling site, concentrations of PCBs 153 and 138 were up to 54.5 and $64 \mathrm{ng} \mathrm{g}^{-1}$, respectively. This indicates contamination by PCBs commercial mixtures Delor 103 and Delor 105 below the discharge of municipal waste water treatment plant in Komárov village which also treats waste water from the engineering plant Buzuluk Komárov.

T a b l e 1. Mean concentrations of the individual PCB congeners, $\Sigma 8$ PCBs concentrations and TOC contents in both sediment grain size fractions of the Červený potok.

$\mathrm{T} \mathrm{a} \mathrm{b} \mathrm{u} 1 \mathrm{k} \mathrm{a} 1$. Průměrné koncentrace jednotlivých kongenerů PCB, koncentrace $\Sigma 8$ PCB kongenerů a obsah organické hmoty (TOC) v obou zrnitostních frakcích sedimentů Červeného potoka.

\begin{tabular}{|c|c|c|c|c|c|c|c|c|c|c|}
\hline $\begin{array}{l}\text { Sampling } \\
\text { site }\end{array}$ & PCB 28 & $\begin{array}{c}\mathrm{PCB} \\
52\end{array}$ & $\begin{array}{c}\text { PCB } \\
101\end{array}$ & $\begin{array}{c}\text { PCB } \\
118\end{array}$ & $\begin{array}{c}\mathrm{PCB} \\
153\end{array}$ & $\begin{array}{c}\mathrm{PCB} \\
138\end{array}$ & $\begin{array}{c}\text { PCB } \\
180\end{array}$ & $\begin{array}{c}\text { PCB } \\
194 \\
\end{array}$ & $\Sigma 8 \mathrm{PCB}$ & TOC \\
\hline & {$\left[\operatorname{ng~g}^{-1}\right]$} & {$\left[\operatorname{ng~g}^{-1}\right]$} & {$\left[\mathrm{ng} \mathrm{g}^{-1}\right]$} & {$\left[\mathrm{ng} \mathrm{g}^{-1}\right]$} & {$\left[\operatorname{ng~g}^{-1}\right]$} & {$\left[\mathrm{ng} \mathrm{g}^{-1}\right]$} & {$\left[\mathrm{ng} \mathrm{g}^{-1}\right]$} & {$\left[\operatorname{ng~g}^{-1}\right]$} & {$\left[\mathrm{ng} \mathrm{g}^{-1}\right]$} & [mass \%] \\
\hline & \multicolumn{10}{|c|}{$<2 \mathrm{~mm}$ fraction } \\
\hline 1 & 3.3 & $<1.0$ & 4.6 & $<1.0$ & 2.4 & 1.8 & 1.6 & $<1.0$ & 15.3 & 0.7 \\
\hline 2 & 39.9 & $<1.0$ & 12.8 & N.D. & 9.1 & 10.1 & 3.4 & 2.8 & 78.9 & 3.7 \\
\hline 3 & 737 & 71.9 & 52.2 & 11.6 & 43.1 & 44.9 & 18.0 & 17.7 & 997 & 12.6 \\
\hline 4 & 174 & 17.5 & 29.1 & 2.7 & 34.4 & 48.7 & 18.2 & 4.8 & 330 & 6.5 \\
\hline 5 & 132 & 7.2 & 10.4 & $<1.0$ & 13.8 & 13.8 & 6.3 & 6.8 & 192 & 5.5 \\
\hline \multirow[t]{2}{*}{6} & 152 & 14.8 & 32.1 & 5.8 & 30.1 & 38.1 & 19.0 & 7.1 & 299 & 11.1 \\
\hline & \multicolumn{10}{|c|}{$<200 \mu \mathrm{m}$ fraction } \\
\hline 1 & 6.9 & 1.1 & 4.8 & N.D. & 7.3 & 5.9 & 2.7 & 1.1 & 29.9 & 4.0 \\
\hline 2 & 42.0 & 1.5 & 15.3 & N.D. & 14.1 & 11.5 & 5.1 & 2.1 & 91.6 & 3.7 \\
\hline 3 & 575 & 81.2 & 97.2 & 34.4 & 54.5 & 64.0 & 34.7 & 11.1 & 952 & 11.3 \\
\hline 4 & 200 & 21.8 & 44.0 & 10.7 & 34.2 & 36.8 & 19.3 & 5.1 & 372 & 3.7 \\
\hline 5 & 262 & 22.4 & 49.7 & 10.4 & 31.8 & 38.1 & 16.7 & 6.5 & 438 & 7.3 \\
\hline 6 & 146 & 14.6 & 65.8 & 8.9 & 34.3 & 46.6 & 22.1 & 7.1 & 346 & 9.6 \\
\hline
\end{tabular}


$<2 \mathrm{~mm}$ fraction

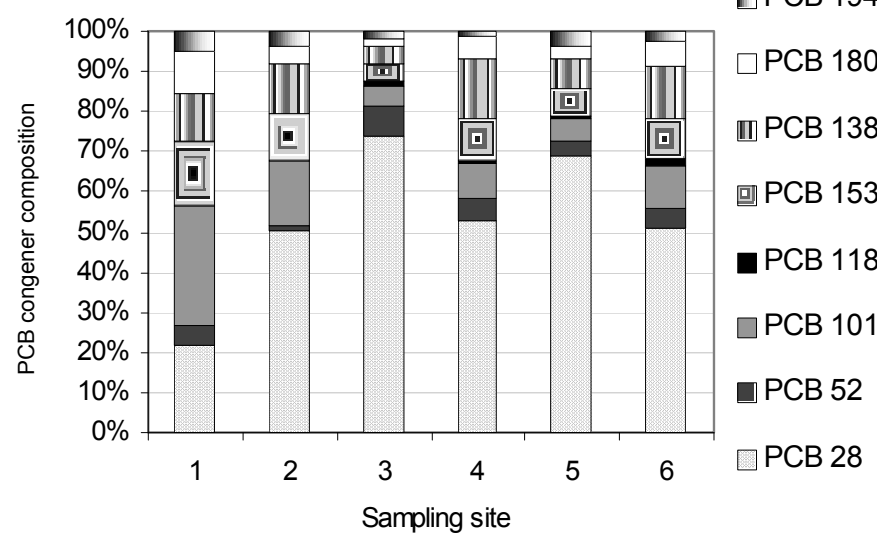

$<200 \mu \mathrm{m}$ fraction

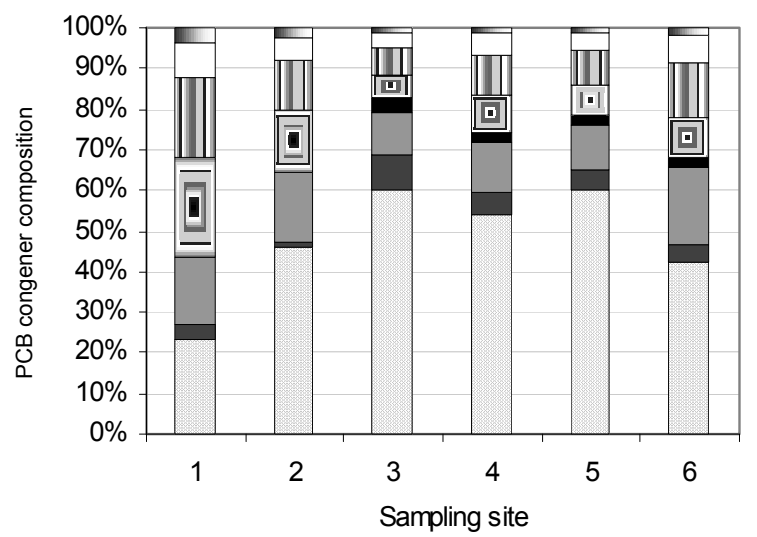

Fig. 2. Composition of individual PCB congeners in both sediment grain size fractions. Obr. 2. Kongenerové složení PCB v obou zrnitostních frakcích sedimentů.

Taniyasu et al. (2003) reported trichlorobi p-henyl congener 28 to be the most abundant congener found in Delor 103 accounting for $29 \%$ of the total chlorobiphenyl content, whereas penta- and hexa-chlorobiphenyls were the dominant congeners in Delor 105. In Delor 105 hexa-CB congeners 138 and 153 were the most abundant ones, together accounting for $25 \%$ of the total chlorobiphenyl content. In 1967 and 1968, the production of Delors 103 and 105 was initiated in the former Czechoslovakia for use in transformers and capacitors $(\mathrm{Ho}-$ loubek, 2000). These technical mixtures are generally comparable to Aroclors 1242 and 1254 (Schulz et al., 1989). Delor 103 was used as a dielectric fluid in capacitors and Delor 105 was used in transformers manufactured in the Czech Republic.

In the first sampling site, the concentrations of $\Sigma 8$ PCBs were 15.3 and $29.9 \mathrm{ng} \mathrm{g}^{-1}$ in sediment grain size fraction $<2 \mathrm{~mm}$ and $<200 \mu \mathrm{m}$, respectively. This contamination of the background area near the spring of the Červený potok is evident due to the intensity of atmospheric transport of PCBs. In the first sampling site, low-chlorinated PCB 28 represented about $21 \%$ of the total amount of PCBs. Nondek and Frolikova (1991), who published strong contamination (100-1900 ng g ${ }^{-1}$ PCBs) of bottom sediments of Labe River and Jizera River in the Czech Republic, reported that the intensity of atmospheric transport to non-industrialized areas (Šumava Mountains) was comparable with that reported in the USA during the 1970's.

High contamination of the Červený potok sediments, up to $997 \mathrm{ng} \mathrm{g}^{-1}$ of $\Sigma 8$ PCBs, is also signifi- cant in comparison with other watersheds in Central and Eastern Europe monitored in the last decade. In sediments of Zemplínska šírava water reservoir (Slovakia), the concentrations up to $547 \mathrm{ng} \mathrm{g}^{-1}$ of $\Sigma 9$ PCBs were measured (Dercová et al., 2009). In sediments of the Elbe River (Czech Republic) and the Odra River (Poland) the concentrations up to 345 and $349 \mathrm{ng} \mathrm{g}^{-1}$ were reported, respectively (Rudiš et al., 2009; Wolska et al., 2003).

It has been known that PCBs associate mainly with organic carbon-rich particles and positively correlated with organic carbon contents (Iwata et al., 1995; Sanders et al., 1996). Fig. 3 shows concentrations of individual PCB congeners normalized to TOC content in both sediment fractions. The results indicates that the more highly chlorinated PCB congeners tend to be more associated with finer organic carbon particles of the $<200 \mu \mathrm{m}$ sediment fraction. Sorption of PCBs onto sediment can be characterized by a combination of absorption by amorphous organic matter (biopolymers) and extensive adsorption onto carbonaceous geosorbents (e.g., coal, soot, and kerogens) (Gdaniec-Pietryka et al., 2007). The higher percentage of the more highly chlorinated PCB congeners associated with the $<200 \mu \mathrm{m}$ sediment fraction could be explained by higher content of highsurface area carbonaceous material (HSACM), which is largely responsible for the nonlinear sorption of nonpolar organic pollutants.

The result of PCA revealed that the first principal component (FAC1) accounted for $92.7 \%$ of the total variance (Fig. 4). This component had positive 
loadings on all PCB congeners and TOC. The gradient along the $\mathrm{X}$-axis from the left to the right indicates an increase in PCBs contamination. Two samples located in the left side of PCA plot are upstream samples located above the source of pollution in the Komárov village. On the contrary, the most contaminated sample 3 is located on the right side of the plot. The second principal component (FAC2, $4.5 \%$ of total variance) had positive loadings on TOC and highly chlorinated PCB congeners except PCB 118. This supports the fact that the second principal component is the geochemical factor, in which concentrations of associated highly chlorinated PCB congeners depend on TOC contents. Isomers with higher chlorine content bind preferentially to organic matter present in the solid phase; they are not easily degraded and are poorly extracted from sediments by water (Holoubek, 2000; Gdaniec-Pietryka et al., 2007).
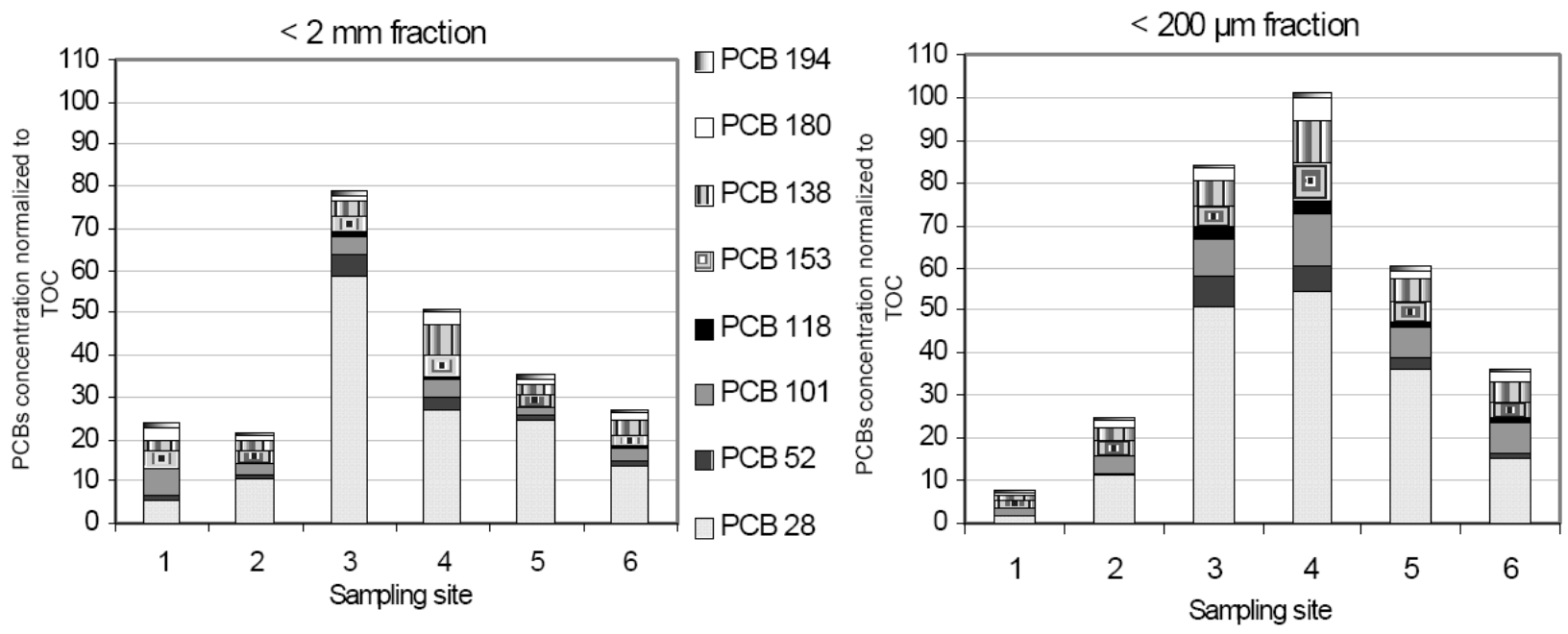

Fig. 3. Concentrations of individual PCB congeners normalized to TOC content in both sediment fractions.

Obr. 3. Koncentrace jednotlivých kongenerů PCB v obou zrnitostních frakcích sedimentů vztažené na jednotku obsahu organické hmoty (TOC).

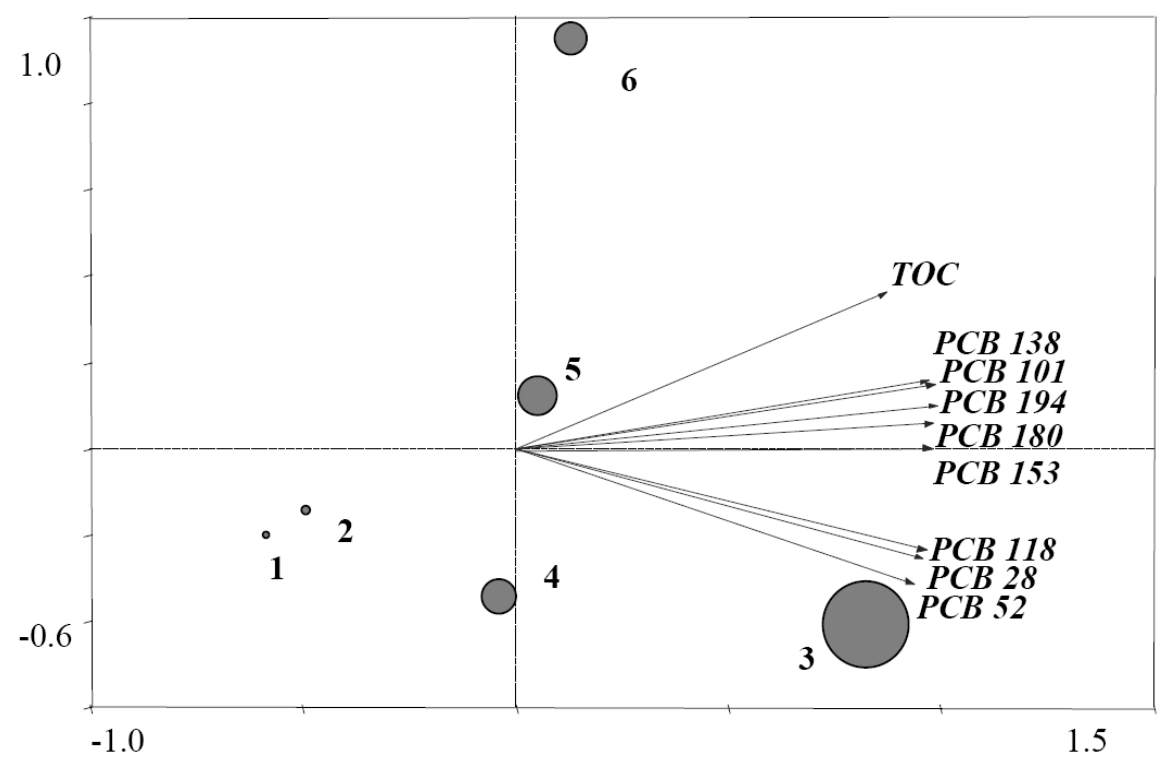

Fig. 4. Principal component score plot of the first and second factors accounting for $97.2 \%$ of the total variance; 6 sediment samples of $<200 \mu \mathrm{m}$ grain size fraction. The dark bubble areas are proportional to $\Sigma 8$ PCBs concentration in the sediment samples.

Obr. 4. Graf analýzy hlavních komponent (PCA) zobrazující první a druhou faktorovou osu, které vysvětlují 97.2\% celkové variability dat; 6 vzorků sedimentů zrnitostní frakce $<200 \mu \mathrm{m}$. Plocha tmavých kruhů je proporcionální k $\Sigma 8$ PCB kongenerů $\mathrm{v}$ jednotlivých vzorcích sedimentů. 


\section{Conclusion}

PCB indicator congeners $(28,52,101,118,138$, 153,180 and 194) were observed in most of the investigated sediment samples. In the sampling site 3 located in Komárov village, the highest $\Sigma 8$ PCB concentrations 997 and $952 \mathrm{ng} \mathrm{g}^{-1}$ (dry weight) were found in both sediment grain size fractions $<2$ $\mathrm{mm}$ and $<200 \mu \mathrm{m}$, respectively.

Concentrations and composition of individual PCB congeners indicate the contamination by PCBs commercial mixtures Delor 103 and Delor 105 (an equivalent of AROCLOR 1242 and 1254) below the discharge of municipal waste water treatment plant in Komárov village which also treats waste water from the engineering plant Buzuluk Komárov. These PCBs technical mixtures were used as technical fluids in transformers and capacitors in the Czech Republic. The most abundant PCB congener 28 constituted up to $73 \%$ of the total amount of PCBs, PCB congeners 153 and 138 constituted up to $22 \%$ and $20 \%$ of the total amount of PCBs, respectively.

The results of PCBs concentrations normalized to TOC content as well as the results of PCA analysis indicate that the more highly chlorinated PCB congeners tend to be more associated with finer organic carbon particles of $<200 \mu \mathrm{m}$ sediment fraction, which could be explained by higher content of HSACM, which significantly affects the sorption of hydrophobic contaminants.

Acknowledgement. The research project has been funded by the Grant Agency AS CR under the project No. IAA200600902 and Institutional Research Plan No. AVOZ20600510. The authors acknowledge the financial assistance on this project.

\section{REFERENCES}

BREIVIK K., SWEETMAN A., PACYNA J.M., JONES K.C., 2002: Towards a global historical emmission inventory for selected PCB congeners - a mass balance approach: 1 . Global production and consumption. Sci. Total Environ., 290, 181-198.

DERCOVÁ K., ŠELIGOVÁ J., DUDÁŠOVÁ H., MIKULÁŠOVÁ M., ŠILHÁROVÁ K., TÓTHOVÁ L., HUCKO P., 2009: Characterization of the bottom contamined sediments with polychlorinated biphenyls: Evaluation of ecotoxicity and biodegradability. Int. Biodeter. Biodegr., 63, 440-449.

GDANIEC-PIETRYKA M., WOLSKA L., NAMIEŚNIK, J., 2007: Physical speciation of polychlorinated biphenyls in the aquatic environment. Trend. Anal. Chem., 26, 1005-1012 .
HNAŤUKOVÁ P., BENEŠOVÁ L., KOMÍNKOVÁ D., 2009: Impact of urban drainage on metal distribution in sediments of urban streams. Wat. Sci. Tech., 59, 1237-1246.

HOLOUBEK I., 2000: Polychlorinated Biphenyls (PCBs) World-Wide Contaminated Sites. TOCOEN REPORT No. 173. http://www.recetox.muni.cz/res/file/reporty/to-coenreport 173-id438.pdf

HULSCHER T.E.M., VRIND B.A., VAN NOORT P.C.M., GOVERS H.A.J., 2002: Resistant sorption of in situ chlorobenzenes and a polychlorinated biphenyl in river Rhine suspended matter. Chemosphere, 49, 1231-1238.

IWATA H., TANABE S., UEDA K., TATSUKAWA R., 1995: Persistent organochlorine residues in air, water, sediments and soils from the Lake Baikal region, Russia. Environ. Sci. Technol., 29, 792-801.

KRAUSS M., WILCKE W., ZECH W., 2000: Polycyclic aromatic hydrocarbons and polychlorinated biphenyls in forest soils: depth distribution as indicator of different fate. Environ. Pollut., 110, 79-88.

NAKATA H., SAKAI Y., MIYAWAKI T., TAKEMURA A., 2003: Bioaccumulation and toxic potencies of polychlorinated biphenyls and polycyclic aromatic hydrocarbons in tidal and coastal ecosystems of the Ariake Sea, Japan. Environ. Sci. Technol., 37, 3513-3521.

NONDEK L., FROLIKOVA N., 1991: Polychlorinated biphenyls in the hydrosphere of Czechoslovakia. Chemosphere, 23, 269-280.

RUDIŠ M., VALENTA P., VALENTOVÁ J., NOL O., 2009: Assessment of the deposition of polluted sediments transferred by a catastrophic flood and related changes in groundwater quality. Journal of Hydrology, 369, 326-335.

SAFE S., 1990: Polychlorinated biphenyls (PCBs), dibenzo-pdioxins (PCDDs), dibenzofurans (PCDFs), and related compounds: environmental and mechanistic consideration which support the development of toxic equivalence factors (TEFs). Crit. Rev. Toxicol., 21, 51-88.

SAMARA F., TSAI C.W., AGA D.S., 2006: Determination of potential sources of PCBs and PBDEs in sediments of the Niagara River. Environ. Pollut., 139, 489-497.

SANDERS G., HAMILTON-TAYLOR J., JONES K.C., 1996: PCB and PAH dynamics in a small rural lake. Environ. Sci. Technol., 30, 2958-2966.

SCHULZ D.E., PETRICK G., DUINKER J.C., 1989: Complete characterisation of polychlorinated biphenyl congeners in commercial Aroclor and Chlophen mixtures by multidimensional gas chromatographyelectron captive detection. Environ. Sci. Technol., 23, 852-859.

SKOTVOLD T., SAVINOV V., 2002: Regional distribution of PCBs and presence of technical PCB mixtures in sediments from Norwegian and Russian Arctic Lakes. Sci. Total Environ., 306, 85-97.

TANABE S., 1988: PCB problems in the future: foresight from current knowledge. Environ. Pollut., 50, 5-28.

TANIYASU S., KANNAN K., HOLOUBEK I., ANSORGOVA A., HORII Y., HANARI N., 2003: Isomer-specific analysis of chlorinated biphenyls, naphthalenes and dibenzofurans in Delor: polychlorinated biphenyl preparations from the former Czechoslovakia. Environ. Pollut., 126, 169-178.

TER BRAAK C. J. F., SMILAUER P., 2002: CANOCO Reference Manual and CanoDraw for Windows User's Guide: Software for Canonical Community Ordination (version 4.5). Microcomputer Power, Ithaca, New York, USA. 
VOLAUFOVÁ L., LANGHAMMER J., 2007:Specific pollution of surface water and sediments in the Klabava River basin. J. Hydrol. Hydromech., 55, 2, 122-134.

WOLSKA L., ZYGMUNT B., NAMIESNIK J., 2003: Organic pollutants in the Odra river ecosystem. Chemosphere, 53, 561-569.

Received 8 September 2009 Accepted 14 October 2009

\section{DISTRIBUCE PCB V SEDIMENTECH ČERVENÉHO POTOKA KONTAMINOVANÉHO TECHNICKÝMI SMĚSMI DELOR, ČESKÁ REPUBLIKA}

Petra Hnat'uková, Helena Burešová, Lucie Kochánková, Jitka Bäumeltová

Polychlorované bifenyly (PCB) patřící k tzv. persistentním organickým polutantům (POP) představují velkou environmentální zátěž, jelikož jsou velice špatně rozložitelné a zdržují se v životním prostředí po dlouhou dobu. Jsou kumulativní a ohrožují zdraví organismů včetně člověka i v poměrně nízkých koncentracích. Vzhledem k fyzikálním vlastnostem PCB, jako je nízká rozpustnost ve vodě a schopnost sorpce na organickou hmotu, dochází ve vodním prostředí $\mathrm{v}$ sedimentech $\mathrm{k}$ jejich významné kumulaci.

V České republice jsou polychlorované bifenyly nejproblémovější skupinou POP z důvodu výroby a hojného používání na našem území ještě v době, kdy už byly ve světě známy jejich negativní dopady. Ačkoliv výroba PCB, která od roku 1959 probíhala v chemickém závodě Chemko Strážské v bývalém Československu, byla $\mathrm{v}$ roce 1984 zakázána, je $\mathrm{z}$ důvodu jejich dlouhého setrvání v prostř̌edí naše území pod vlivem zvýšené zátěže dodnes.

Příspěvek se zabývá sledováním množství PCB v sedimentech Červeného potoka v povodí Litavky, kde se dlouhodobě objevuje jejich zvýšená koncentrace. Z výsledků vyplývá, že přestože se jedná o drobný povrchový tok, dosahuje současná kontaminace jeho sedimentů úrovně, které dosahovaly zatížené sedimenty Labe v počátku 90. let.
Na jaře roku 2008 byly odebrány vzorky sedimentů na 6 odběrových místech v podélném profilu Červeného potoka, $\mathrm{z}$ nichž dvě se nacházela nad zdrojem kontaminace a čtyři pod ním (obr. 1). Vzorky sedimentů byly lyofilizovány a rozsítovány na zrnitostní frakce $<2 \mathrm{~mm}$ $\mathrm{a}<200 \mu \mathrm{m}$ a následně extrahovány Soxhletovou extrakcí a předčištěny metodou SPE na florisilu. Koncentrace osmi indikačních kongenerů PCB (PCB 28, 52, 101, 138, 153,180 a 194) byly měřeny metodou plynové chromatografie s ECD detekcí. Dále byl vyhodnocen obsah organické hmoty (TOC) v sedimentech.

Celkové koncentrace PCB se v zrnitostní frakci $<2$ mm pohybovaly od 15,3 do $997 \mathrm{ng} \mathrm{g}^{-1}$ sušiny, ve frakci < $200 \mu \mathrm{m}$ bylo rozpětí koncentrací 29,9 až $952 \mathrm{ng} \mathrm{g}^{-1}$ sušiny (tab. 1). Kongenery PCB 28, 52, 101, 138, 153, 180 a 194 byly naměřeny ve všech vzorcích sedimentů. Nejvyšší koncentrace $\Sigma 8$ kongenerů PCB byla naměřena na odběrovém místě č. 3 v obci Komárov, dále po směru toku se množství PCB v sedimentech snižovalo. Odběrový profil č. 3 se nacházel pod zaústěním odtoku z ČOV v obci Komárov, která čistí i odpadní vody z místního strojírenského podniku Buzuluk Komárov. Nejnižší koncentrace byly naměřeny proti proudu od zdroje kontaminace na odběrovém místě č. 2 a 1 . Koncentrace PCB pozitivně korelovala s obsahem organické hmoty v sedimentu (\% TOC). Po přepočtu koncentrací jednotlivých kongenerů PCB na jednotku TOC se ukázalo, že na jemnější frakci sedimentu $(<200 \mu \mathrm{m})$ se váže více PCB (obr. 3).

Největší procentuální zastoupení měl u všech odběrových profilů kromě prvního nízkochlorovaný kongener PCB 28. Výšechlorované kongenery PCB se přednostně sorbovaly na jemnější zrnitostní frakci $<200$ $\mu \mathrm{m}$ a jejich podíl ve vzdálenějších místech od zdroje kontaminace se zvyšoval. Kongenerové složení kontaminace s dominancí kongenerů PCB 28 (22-74\%), PCB $153(5-22 \%)$ a PCB $138(5-20 \%)$ v $\Sigma 8$ kongenerů PCB indikuje znečištění technickými směsmi Delor 103 a Delor 105, které jsou svým kongenerovým složením srovnatelné se směsmi AROCLOR 1242 a 1254. 